\title{
Influence of Modified Atmosphere Packaging and Cold Storage on Antioxidants Activity and Storability of Peach Fruit
}

\author{
Hoda A. Galal ${ }^{*}$, R. R. Khalil ${ }^{* *}$, Aida M. Allam* \\ *Environmental Studies and Research Institute (ESRI), \\ University of Sadat City, Menofeia and ${ }^{* *}$ Department of \\ Botany, Faculty of Science, Benha University, Benha, Egypt.
}

\begin{abstract}
D HysicO-CHEMICAL responses and antioxidants activity of peach fruit (Prunus persica, L.) cv. "Succary" stored at modified atmosphere packaging (MAP) using shrink film at room temperature $\left(25^{\circ} \mathrm{C}\right)$ and cold storage $\left(6^{\circ} \mathrm{C}\right)$ were investigated. Results indicated that the individual treatment with MAP or cold storage was found insufficient to delay ripening and to maintain quality for long period. The combination of MAP and cold storage $\left(\mathrm{MAP}+6^{\circ} \mathrm{C}\right)$ was an effective technique to delay fruit ripening and to extend storage period up to 31 days throughout a reduction in fruit weight loss, fruit softening and membrane damage, in addition to maintaining the activity of antioxidant enzymes (catalase, peroxidase and superoxide dismutase) at a high level.
\end{abstract}

Keywords: Prunus persica, MAP, Catalase, Peroxidase, Superoxide dismutase, Electrolyte leakage.

\author{
Abbreviations: Catalase (CAT), Electrolyte leakage (EL), Modified \\ atmosphere packaging (MAP), Peroxidase (POD), \\ Reactive oxygen species (ROS), Superoxide dismutase \\ (SOD), Total soluble solids (TSS).
}

Peach (Prunus persica, L.) is one of the most important deciduous fruit tree grown in Egypt. In 2012, peach production reached about 107,171 tonnes (FAO, 2014). Postharvest handling of peach fruits is a challenge due to rapid deterioration. Peach storage at room temperature is very short ( $\approx 5$ days) (Tonini and Tura, 1998), and this is due to rapid compositional changes and degradation processes, high respiration rate and water loss, and increased susceptibility to pathogens (Bonghi, 1999, An et al., 2007 and Mohsen, 2011).

Cold storage has been widely used to slow down ripening and senescence processes in fruit crops. In peach, cold storage may limit storage period due to fruit susceptibility to chilling injury (Lurie \& Crisosto, 2005 and Shinya et al., 2014) and the production of reactive oxygen species (ROS) (Mittler et al., 2004 and Scandalios, 2005). The accumulation of ROS in the cells results in damage of macro-molecules such as DNA, protein and lipids. The degree of damage 
depends on the balance between ROS production and their removal by efficient enzymatic and non-enzymatic antioxidant scavenging system (Scandalios, 1993 and Sies, 1997).

In developing countries, cold storage requires special facilities, which may affect the final price of the commodity, so that some growers may use cold conditions during transportation, but not at local markets to lower the cost. Modified atmosphere packaging (MAP) is one of the storage techniques that was developed to reduce postharvest loss and preserve fruit quality (An et al., 2007, Ozkaya et al., 2009 and Pongener et al., 2011). Modified atmosphere generally reduces oxygen and elevates carbon dioxide concentration in the ambient atmosphere of the fruit. Under these conditions, the fruit respiration rate decrease, and hence the consumption of respiration substrates such as sugars and organic acids are reduced (Ding et al., 2002). Modified atmosphere packaging has some advantages on the storability of fruit and vegetables, since it improves membrane integrity and reduces the rate of water loss. It also prolongs the activity of antioxidant enzymes such as: superoxide dismutase, catalase and peroxidase (Wang et al., 2005), inhibits the climacteric peak, reduces the development of softness, and limits the reduction in total soluble solids (TSS) and titratable acidity (An et al., 2006 and Pongener et al., 2011). On the other hand, MAP may also lead to off flavor (Peng and Sutton, 1991), discoloration (degradation of chlorophylls, carotenoids and anthocyanins), softening, skin and flesh browning (Ding et al., 2002).

Therefore, the objective of this study was to evaluate the influence of modified atmosphere packaging (MAP) and cold storage on storability, fruit quality and antioxidants activity of peach fruit.

\section{Experiment}

\section{Materials and Methods}

This study was carried out during 2013 and 2014 seasons. Peach fruit (Prunus persica cv. "Succary") of white flesh and low acidity were obtained from a commercial orchard at Cairo-Alexandria desert road, Egypt. Mature fruits were harvested manually and transported to the laboratory within 3 hours. Fruits were dry-cleaned and selected for their uniformity of size and appearance, and free of pathogen infections or physical damages. Fruits were packed in single layer foam trays with 9 fruits $(650-750 \mathrm{~g})$ each. Fruits were divided into two similar groups. Fruits of the first group were wrapped with commercial shrink film for a modified atmosphere conditions (MAP), as recommended by Pongener et al. (2011), with four holes of $1 \mathrm{~mm}$ in diameter to prevent the condensation of water vapor inside the packages (Singh and Mandal, 2006). Fruits of the second group were left without wrapping (C). Both MAP and $\mathrm{C}$ groups were divided into two sub-groups and one of each was stored at room temperature $\left(25 \pm 3^{\circ} \mathrm{C}, 65-70 \%\right.$ $\mathrm{RH})$ and the other one was stored at $\left(6 \pm 2^{\circ} \mathrm{C}, 85 \% \mathrm{RH}\right)$. The four treatments were as follow: MAP $+6^{\circ} \mathrm{C}$, MAP $+25^{\circ} \mathrm{C}, \mathrm{C}+6^{\circ} \mathrm{C}$ and $\mathrm{C}+25^{\circ} \mathrm{C}$ (control). Fruit characteristics were assessed at harvest, and then twice a week until $50 \%$ decay appear, moment in which the storage period was ended in both seasons.

Egypt. J. Hort. Vol. 43, No.2 (2016) 
Fruit physical and chemical characteristics

All trays were used to estimate fruit weight loss \% in each treatment. Three replicates (two fruits each) were used to determine different physical and chemical characteristics. Various fungal symptoms on stored fruit were observed and calculated as decay percentage. Flesh firmness (lb.inch-2) was measured using a portable penetrometer (Effegi- Milan, Italy), with a $7.9 \mathrm{~mm}$ probe. Total soluble solids (TSS) were measured with a thermo-balanced refractometer (Atago, Tokyo, Japan). Titratable acidity percentage (TA) was determined as malic acid, since it is the major organic acid in peach fruit (Moing et al., 1998) by titration using $0.1 \mathrm{~N}$ of $\mathrm{NaOH}$, according to A.O.A.C. (1980).

\section{Determination of membrane permeability}

Membrane permeability was determined based on electrolyte leakage, as described by Montoya et al. (1994). Ten discs (2-3 mm thickness and $10 \mathrm{~mm}$ diameter) were excised from the fruit pulp using a cork borer and washed with distilled water to remove the sap from ruptured cells, and then placed in a beaker in $100 \mathrm{ml} 0.4 \mathrm{M}$ mannitol. After incubation at $25^{\circ} \mathrm{C}$ for 4 hours, the conductivity of the suspending solution was measured with a conductivity meter (CM-30ET). The beakers were covered with aluminum foil and autoclaved at $121^{\circ} \mathrm{C}$ for 30 min to liberate all electrolytes, and then measured again as $100 \%$ leakage. Measurements were carried out in triplicate, and average was calculated. Electrolyte leakage was expressed by the following equation:

Total ion leakage $(\%)=($ initial reading $/$ final reading $) \times 100$.

Determination of antioxidant enzymes activity

The preparation of samples for enzyme extraction was according to the method described by Mukherjee and Choudhurri (1983). Superoxide dismutase (SOD, EC 1.15.1.1) activity was measured according to the method of Dhindsa et al. (1981) by determining its ability to inhibit the photochemical reduction of nitro blue tetrazolium (NBT). One unit of SOD was defined as the amount of the enzyme that caused half the maximum inhibition of NBT reduction to blue formazan at $560 \mathrm{~nm}$ under the experimental conditions. Catalase (CAT, EC 1.11.1.6) activity was assayed in a reaction mixture $(3 \mathrm{ml})$ composed of phosphate buffer (50 mM, pH 7.0), 30\% (w/v) H2O2 and $0.5 \mathrm{ml}$ enzyme extract (Aebi, 1983). Catalase activity was estimated by the reduction in absorbance at $240 \mathrm{~nm}$ using a Spectronic $601 \mathrm{UV}$ spectrophotometer, as a consequence of $\mathrm{H} 2 \mathrm{O} 2$ consumption, and was expressed in accordance to Havir and McHale (1987) as $\mu \mathrm{M}$ H2O2 oxidized $\mathrm{g}-1$ fresh weight (FW) min-1. Peroxidase (POD, EC 1.11.1.7) activity was determined using guaiacol. The reaction mixture $(3 \mathrm{ml})$ was composed of $10 \mathrm{mM} \mathrm{KH} 2 \mathrm{PO} 4-\mathrm{K} 2 \mathrm{HPO} 4$ (pH 7.0), $10 \mathrm{mM} \mathrm{H} 2 \mathrm{O} 2,20 \mathrm{mM}$ guaiacol and $0.5 \mathrm{ml}$ crude extract (Malik and Singh, 1980). The increase in absorbance as a result of dehydrogenation of guaiacol was monitored at $470 \mathrm{~nm}$ (Klapheck et al., 1990) using a Spectronic 601 UV spectrophotometer. Enzyme activity was expressed as a change in the optical density g-1 FW min-1. 
Statistical analysis

The experiment was conducted in a completely randomized design (Snedecor and Cochran, 1989), as a factorial experiment including two types of MAP (with and without wrapping) and two storage temperatures $\left(25\right.$ and $\left.6^{\circ} \mathrm{C}\right)$. The analysis of variance (ANOVA) was tested using SPSS Version 11.0. Results were expressed as mean \pm standard deviation (SD). Least significance differences (LSDs) were calculated to compare significant effects at $P \leq 5 \%$.

\section{Results}

Data of two seasons revealed that $\mathrm{MAP}+6^{\circ} \mathrm{C}$ extended peach storage life up to 31 days. While unwrapped fruit stored at $6^{\circ} \mathrm{C}$ became shrink and lost its fresh appearance after 14 days of storage. Short storage life of 7 days was observed with both wrapped and unwrapped fruits stored at $25^{\circ} \mathrm{C}$.

\section{Changes in physical characteristics}

Physical characteristics of wrapped and unwrapped fruit stored at 6 and $25^{\circ} \mathrm{C}$ are shown in Fig. 1. Low temperature reduced weight loss significantly $(P \leq 0.05)$, compared to fruit at $25^{\circ} \mathrm{C}$ (Fig. 1-A). At both low and room temperatures, MAP decreased fruit weight loss, reduced shrinkage, and maintained fruit fresh appearance, as compared to unwrapped fruit. The lowest weight loss $(10.6 \%)$ was noticed for $\mathrm{MAP}+6^{\circ} \mathrm{C}$ after 31 days of storage. Fruits at $\mathrm{MAP}+25^{\circ} \mathrm{C}$ and $\mathrm{C}+25^{\circ} \mathrm{C}$ conditions lost 10.1 and $22.9 \%$ of their weight after 7 days, respectively. The weight loss of fruit at $\mathrm{C}+6^{\circ} \mathrm{C}$ conditions reached $18.6 \%$ after 14 days of storage.

There was a continuous decline in fruit firmness with storage period in all treatments. Rapid decrease was observed in the first three days (Fig. 1-B). Cold storage delayed fruit softening, however, there was no significant $(P \leq 0.05)$ effect for wrapping on firmness. Fruit of MAP $+6^{\circ} \mathrm{C}$ showed the highest fruit firmness (3.9 and $3.7 \mathrm{lb}$.inch-2) after 7 and 10 days of storage, respectively, whereas the lowest firmness $\left(0.2 \mathrm{lb}\right.$.inch-2) was recorded at $\mathrm{C}+25^{\circ} \mathrm{C}$ after 7 days.

Membrane permeability was expressed as a percentage of electrolyte leakage (EL \%) (Fig.1-C). Membrane permeability increased in all treatments with storage in all treatments. Cold storage delayed the increase in EL\%. On the other hand, MAP has no effect on EL\% neither at $25^{\circ} \mathrm{C}$ (in the first three days only) nor at $6^{\circ} \mathrm{C}$. After seven days, EL\% increased sharply in fruit of $\mathrm{C}+25^{\circ} \mathrm{C}$ treatment, while the lowest electrolyte leakage was observed in $\mathrm{MAP}+6^{\circ} \mathrm{C}$ and $\mathrm{C}+6^{\circ} \mathrm{C}$ with no significant differences. Rapid increase was recorded for $\mathrm{MAP}+6^{\circ} \mathrm{C}$ after 17 days of storage, and reached the highest value (70.6\%) after 24 days. 

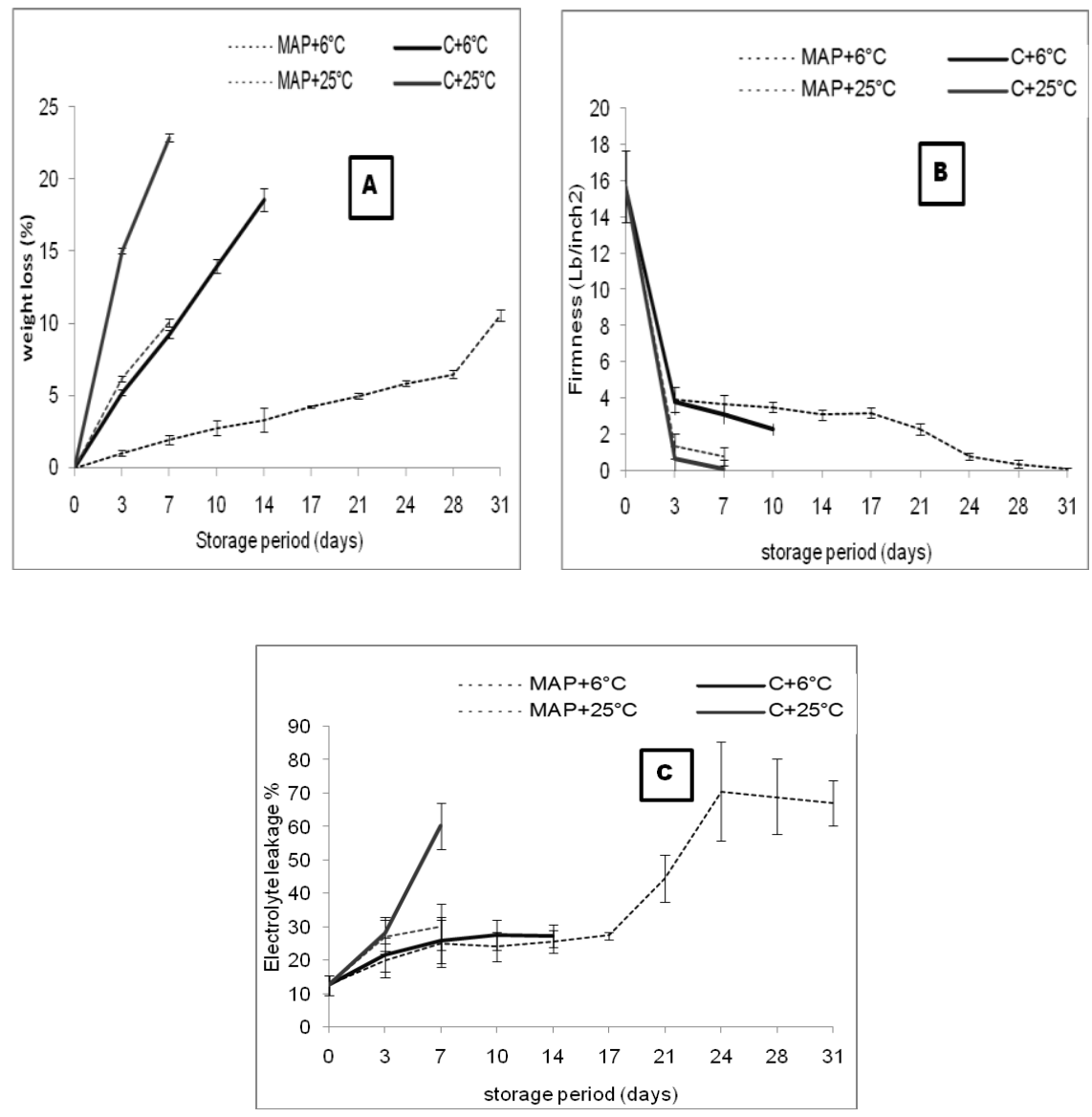

Fig. 1. Effect of wrapped (MAP) and unwrapped (C) packaging on A: weight loss (\%), B: Firmness (Lb/inch2) and C: Electrolyte leakage (\%) of peach fruit stored at room $\left(25^{\circ} \mathrm{C}\right)$ and cold $\left(6^{\circ} \mathrm{C}\right)$ temperature. Data are expressed as mean \pm SD.

The percentage of decay

Cold storage significantly decreased $(P \leq 0.05)$ the percentage of decay of either wrapped or unwrapped fruit (Fig. 2). The highest decay percentage (44 and $30 \%$ ) were recorded after seven days for $\mathrm{MAP}+25^{\circ} \mathrm{C}$ and $\mathrm{C}+25^{\circ} \mathrm{C}$, respectively. Decay percentage of $\mathrm{C}+6^{\circ} \mathrm{C}$ and $\mathrm{MAP}+6^{\circ} \mathrm{C}$ did not increase over $3.5 \%$ and $5 \%$ after 14 and 31 days, respectively. The application of MAP increased decay percentage after 3 days at room temperature $\left(\mathrm{MAP}+25^{\circ} \mathrm{C}\right)$, however, it delayed the appearance of decay at cold temperature $\left(\mathrm{MAP}+6^{\circ} \mathrm{C}\right)$. 


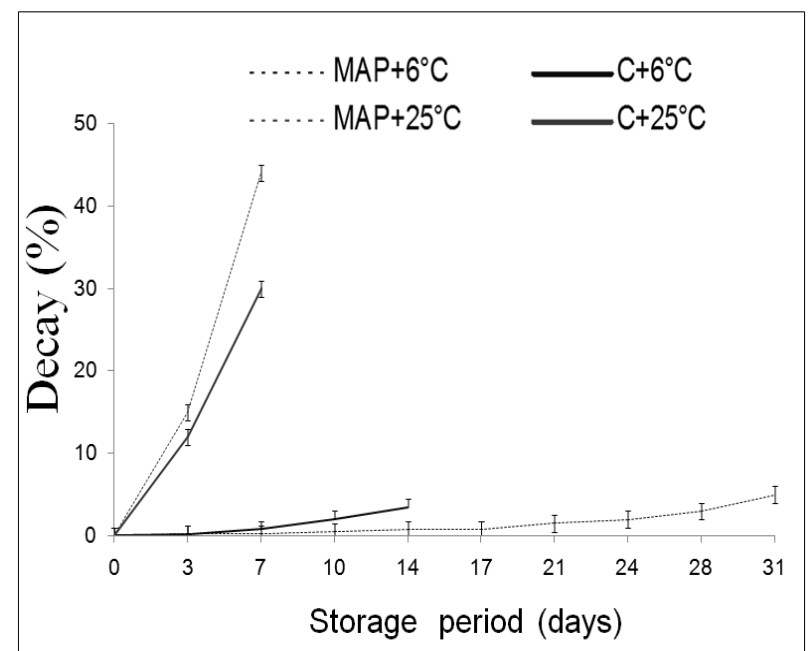

Fig. 2. Effect of wrapped (MAP) and unwrapped (C) packaging on decay (\%) of peach fruit stored at room $\left(25^{\circ} \mathrm{C}\right)$ and cold $\left(6^{\circ} \mathrm{C}\right)$ temperature. Data are expressed as mean \pm SD.

\section{Changes in chemical characteristics}

The changes in TSS and acidity of wrapped and unwrapped fruits stored at room $\left(25^{\circ} \mathrm{C}\right)$ and cold $\left(6^{\circ} \mathrm{C}\right)$ temperature are presented in Fig. 3. For all treatments, TSS increased rapidly within the first three days, while acidity decreased gradually with storage. The level of TSS was in the same trend for all treatments during the first three days of storage. After seven days, the highest TSS $\left(8.5^{\circ}\right.$ Brix) was recorded in MAP $+6^{\circ} \mathrm{C}$, while the lowest $\left(7^{\circ} \mathrm{Brix}\right)$ was recorded in $\mathrm{C}+6^{\circ} \mathrm{C}$. The highest acidity $(1.9 \%)$ was noticed at MAP $+6^{\circ} \mathrm{C}$, but other treatments recorded low acidity with no significant differences among each other.

\section{Changes in antioxidant enzymes activity}

Data illustrated in Fig. 4 showed different patterns of the antioxidant enzymes (CAT, POD and SOD) activity. CAT activity in all treatments showed high level throughout storage compared to the initial value at harvest. CAT activity increased sharply during the first three days in all treatments, except for $\mathrm{MAP}+6^{\circ} \mathrm{C}$, which increased after three days of storage (Fig. 4-A). On the seventh day, there were no significant differences $(P \leq 0.05)$ in CAT activity among all treatments. 

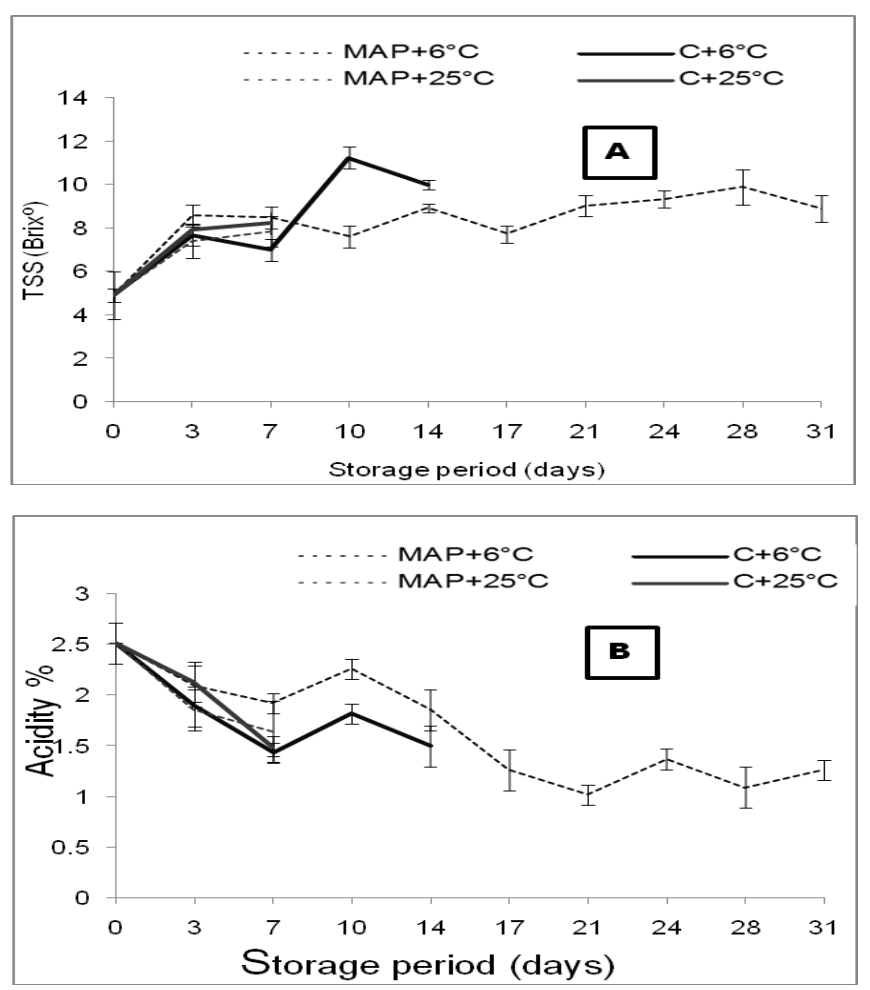

Fig. 3. Effect of wrapped (MAP) and unwrapped (C) packaging on A: TSS $\left({ }^{\circ} \mathrm{Brix}\right)$ and B: titratable acidity (\%) of peach fruit stored at room $\left(25^{\circ} \mathrm{C}\right)$ and cold $\left(6^{\circ} \mathrm{C}\right)$ temperature. Data are expressed as mean $\pm \mathrm{SD}$.

The activity of SOD increased during the first three days in all treatments, except for MAP $+6^{\circ} \mathrm{C}$ (Fig. 4-C). After three days of storage, SOD activity increased rapidly in both $\mathrm{C}+25^{\circ} \mathrm{C}$ and $\mathrm{C}+6^{\circ} \mathrm{C}$ treatments, whereas it increased slowly for MAP $+6^{\circ} \mathrm{C}$.

\section{Discussion}

Effects of MAP and low temperature on physical and chemical characteristics of peach fruit during storage

Peach is a highly perishable climacteric fruit. During ripening, many physical and chemical changes take place causing changes in fruit texture, color and flavor, which increase fruit susceptibility to pathogens (Bonghi, 1999 and An et al., 2007). Results showed that most physical and chemical changes occured sharply after three days of storage, and this may be due to the onset of the climacteric peak, which is associated with increase in respiration rate and ethylene production (Ullah et al., 2015). 


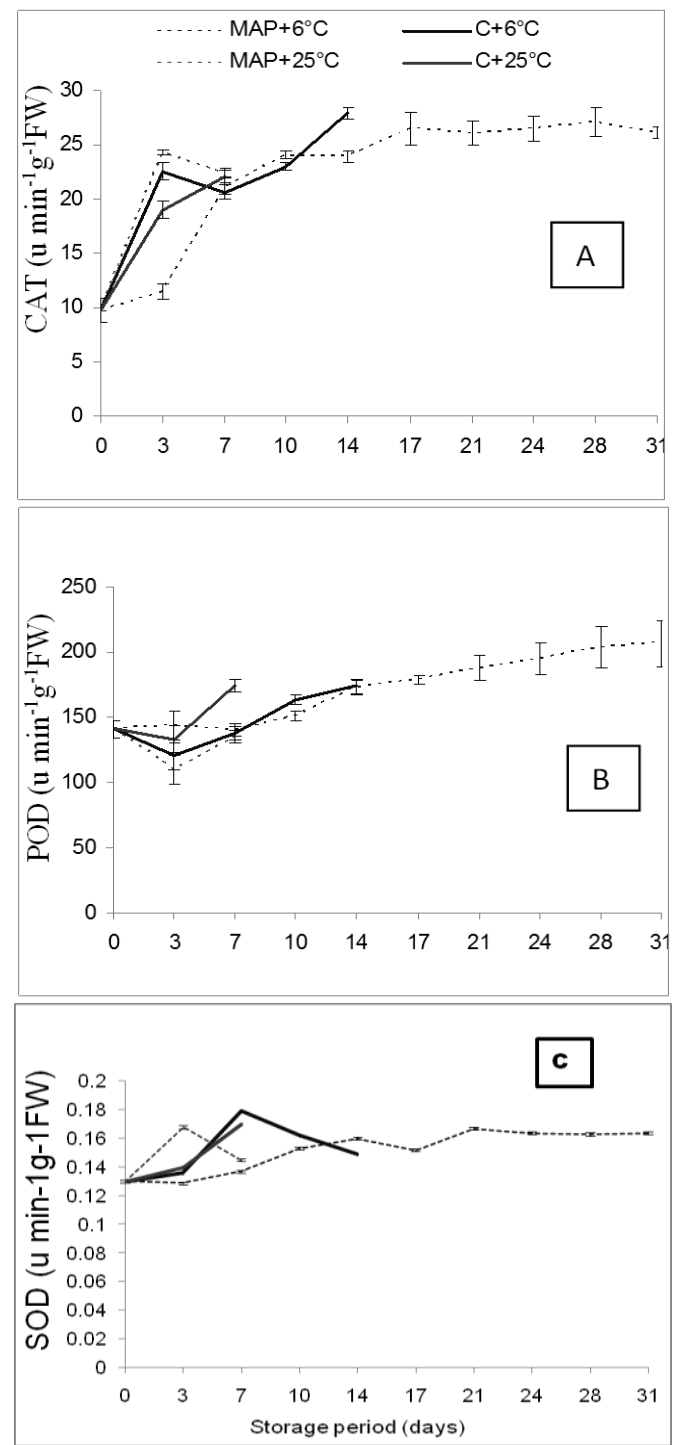

Fig. 4. Effect of wrapped (MAP) and unwrapped (C) packaging on the activity of CAT, POD and SOD enzymes of peach fruit stored at room $\left(25^{\circ} \mathrm{C}\right)$ and cold $\left(6^{\circ} \mathrm{C}\right)$ temperature. Data are expressed as mean $\pm \mathrm{SD}$.

Modified atmosphere and low temperature conditions were studied earlier in many vegetable and fruit crops. Researchers concluded that these conditions increase fruit storability as they slow down respiration rate and all physiological activities, and delay senescence (Wills et al., 2007) and softening by delaying the activity of fruit softening enzymes (Pongener et al., 2011 and Ullah et al., 2015). However, our results revealed that cooling is more effective than MAP in Egypt. J. Hort. Vol. 43, No.2 (2016) 
increasing the storability of peach fruit. The combination of MAP and cooling $\left(\mathrm{MAP}+6^{\circ} \mathrm{C}\right)$ is the most effective treatment as it extends peach storage life up to 31 days. It decreased weight loss, reduced softening and membrane permeability, and delayed the appearance of fungal symptoms.

On the other hand, wrapping increased water vapor accumulation and humidity around the fruit and reduce water evaporation and weight loss at both room and cold temperature, however, it increase fungal infection at room temperature. These results are in agree with those of Mohsen (2011) on peach and apricot.

Fruit firmness is considered one of the most important maturity and ripening indices. The effect of MAP on firmness and electrolyte leakage did not appear in the first three days of storage at 6 and $25^{\circ} \mathrm{C}$, and this maybe that it requires more time to generate a modified atmosphere environment around the fruit by the accumulation of the respiration products.

Modified atmosphere packaging (MAP) and cold storage treatments delayed the increase in TSS and the decrease in acidity, compared to $\mathrm{C}+25^{\circ} \mathrm{C}$ treatment. The lowest TSS value is maybe due to the delay in ripening by MAP and cold storage, which reduced the conversion of starch to sugar. On the other hand, high acidity maybe due to the reduction in organic acid hydrolysis and their accumulation as a result of respiration process (Ding et al., 2002). Same results are recorded by Pongener et al. (2011) on peach fruit packed in different packaging films under cold storage conditions.

Effects of MAP and low temperature on antioxidant enzymes activity of peach fruit during storage

Fruit senescence and deterioration of quality is related to the accumulation of ROS in plant cells (Mittler, 2002). The degree of damage and the storage life depend on the balance between ROS production and scavenging capacity (Hodges et al., 2004). Several antioxidant enzymes such as SOD, CAT and POD play an effective role to protect cells against ROS accumulation (Sies, 1997 and Scandalios, 1993). Superoxide dismutase catalyses the dismutation of superoxide radicals $(\mathrm{O} 2-)$ into either ordinary molecular oxygen $(\mathrm{O} 2)$ or hydrogen peroxide $(\mathrm{H} 2 \mathrm{O} 2)$. Thereafter, catalase and/or peroxidase independently convert $\mathrm{H} 2 \mathrm{O} 2$ to water (Bannister et al., 1987 and Zelko et al., 2002 and Mittler, 2002). Results indicate that exposure to MAP and cold storage in peach may modify the activity of SOD, CAT and POD. The combination of MAP $+6^{\circ} \mathrm{C}$ maintained the antioxidant activity in a high level for long time, which increased its protective role against oxidative damage. These results are in accordance with the findings of Wang et al. (2005) who stated that MAP delays the reduction of superoxide dismutase, catalase and peroxidase activity. The increase in CAT activity and the decrease in POD and SOD during the first three days refer to the vital role of CAT enzyme, as antioxidant, in this period compared to the other enzymes (POD and SOD). 


\section{Conclusion}

In conclusion, The storability of peach fruit could be extended (up to 31 days) with the combination of MAP and cold storage due to their effect on maintaining fruit quality and appearance. Cold storage and MAP delaying ripening and senescence process, reducing fruit weight loss, fruit softening and membrane damage and fungal infection, and delaying the reduction of studied antioxidant enzymes (SOD, CAT and POD). However, this treatment need to be tested on a commercial scale for its effectiveness.

Acknowledgements: Authors would like to thank the Environmental Studies and Research Institute, Sadat City University. They also extend their appreciation to the Faculty of Science, Benha University for the financial support and laboratory facilities to do this research.

\section{References}

A.O.A.C. Association of Official Agriculture Chemists (1980) "Official Methods of Analysis", $13^{\text {th }}$ ed., Washington, DC., USA.

Aebi, H.E. (1983) Catalase. In "Method of Enzymatic Analysis", VCH, Weinheim, Germany-Deerfield, FL. 3, 273-286.

An, J., Zhang, M. and Zhang, Z. (2007) Effect of packaging film on the quality of 'Chaoyang' honey peach fruit in modified atmosphere packages. Packag. Technol. Sci., 20 (1), 71-76.

Bannister, J.V., Bannister, W.H. and Rotilio, G. (1987) Aspects of the structure, function, and applications of superoxide dismutase. CRC Crit. Rev. Biochem., 22 (2), $111-180$

Bonghi, C., Ramina, A., Ruperti, B., Vidrih, R. and Tonutti, P. (1999) Peach fruit ripening and quality in relation to packing time, and hypoxic and high $\mathrm{CO} 2$ short-term postharvest treatment. Postharvest Biology and Technology, 16, 213-222.

Dhindsa, R.S., Plumb-Dhindsa, P. and Thorpe, T.A. (1981) Leaf senescence: correlated with increase leaves of membrane permeability and lipid peroxidation, and decreased levels of superoxide dismutase and catalase. J. Exp. Bot., 32 (1), 93-101.

Ding, C.K., Chachin, K., Ueda, Y., Imahori, Y. and Wang, C.Y. (2002) Modified atmosphere packaging maintains postharvest quality of loquat fruit. Postharvest Biol. Tec., 24, 341-348.

FAO. (2014) Food and Agricultural Organization of the United Nations. http://faostat.fao.org.

Havir, E.A. and McHale, N.A. (1987) Biochemical and developmental characterization of multiple forms of catalase in tobacco leaves. Plant Physiol., 84 (2), 450-455. 
Hodges, D.M., Lester, G.E., Munro, K.D. and Toivonen, P.M.A. (2004) Oxidative stress: importance for postharvest quality. HortScience, 39, 924-929.

Klapheck, S., Zimmer, I. and Cosse, H. (1990) Scavenging of hydrogen peroxide in the endosperm of Ricinus communis by ascorbate peroxidase. Plant Cell Physiol., 31, 1005-1013.

Lurie, S. and Crisosto, C.H. (2005) Chilling injury in peach and nectarine. Postharvest Biol. Technol., 37, 195-208.

Malik, C.P. and Singh, M.B. (1980) Plant enzymology and histo-enzymology. Kalyani publishers, New Delhi, p53.

Mittler, R., Vanderauwera, S., Gollery, M. and Van Breusegem, F. (2004) Reactive oxygen gene network of plants. Trends Plant Sci., 9 (10), 490-498.

Mittler, R. (2002) Oxidative stress, antioxidants and stress tolerance. Trends Plant Sci., 7(9), 405-410.

Mohsen, A.T. (2011) Performance of peach and apricot fruits at cold storage and shelf life as affected by modified atmosphere packaging. American-Eurasian J. Agric. \& Environ. Sci., 10 (5), 718-727.

Moing, A., Svanella, L., Rolin, D., Gaudillere, M., Gaudillere, J.P. and Monet, R. (1998) Compositional changes during the fruit development of two peach cultivars differing in juice acidity. J. Am. Soc. Hortic. Sci., 123, 770-775.

Montoya, M.M., Plaza, J.L. and Lopez-Rodriguez, V. (1994) An improved technique for measuring the electrical conductivity of intact fruit. Lebensm. Wiss. Technol., 27, 34-38.

Mukherjee, S.P. and Choudhuri, M.A. (1983) Implications of water stress-induced changes in the levels of endogenous ascorbic acid and hydrogen peroxide in seedlings. Physiol. Plant., 58 (2), 166-170.

Ozkaya, O., Dundar, O., Scovazzo, G.C. and Volpe, G. (2009) Evaluation of quality parameters of strawberry fruits in modified atmosphere packaging during storage. Afr. J. Biotechnol., 8 (5), 789-793.

Peng, G. and Sutton, J.C. (1991) Evaluation of microorganism for biocontrol of Botrytis cinerea in strawberry. Can. J. Plant Pathol., 13, 247-257.

Pongener, A., Mahajan, B.V.C. and Singh, H. (2011) Effect of different packaging films on storage life and quality of peach fruits under cold storage conditions. Indian J. Hort., 68(2), 240-245.

Scandalios, J.G. (2005) Oxidative stress: Molecular perception and transduction of signals triggering antioxidant gene defenses. Braz. J. Med. Biol. Res., 38 (7), 9951014.

Scandalios, J.G. (1993) Oxygen stress and superoxide dismutase. Plant Physiol., 101 (1), $7-12$. 
Shinya, P., Contador, L., Frett, T. and Infante, R. (2014) Effect of prolonged cold storage on the sensory quality of peach and nectarine. Postharvest Biol. Technol., 95, $7-12$.

Sies, H. (1997) Oxidative stress: oxidants and antioxidants. Exp. Physiol., 82 (2), 291-5.

Singh, D. and Mandal, G. (2006) Post-harvest quality and spoilage of peach fruits stored in perforated poly bags. Indian J. Hort., 63, 390-392.

Snedecor, G.W. and Cochran, W.G., (1989) "Statistical Methods", $8^{\text {th }}$ ed., Iowa State University Press.

Tonini, G. and Tura, E. (1998) Influence of storage and shelf-life time on rots of peaches and nactarines. Acta Hort., 464, 364-367.

Ullah, S., Khan, A.S., Malik, A.U. Shahid M. and Razzaq, K. (2015) Cultivar, harvest location and cold storage influence fruit softening and antioxidative activities of peach fruit [(Prunus persica (L.) batsch]. Pak. J. Bot., 47 (2), 699-709.

Wang, Y.S., Tian, S.P. and Xu, Y. (2005) Effects of high oxygen concentration on proand anti-oxidant enzymes in peach fruits during postharvest periods. Food Chem., 91 (1), 99-104.

Wills, R.B.H., Mc Glasson, W.B., Graham, D. and Joyce, D.C. (2007) Postharvest: An introduction to the physiology and handling of fruit, vegetables and ornamentals. $5^{\text {th }}$ ed., CABI, Wallingford, UK.

Zelko, I.N., Mariani, T.J. and Folz, R.J. (2002) Superoxide dismutase multigene family: a comparison of the CuZn-SOD (SOD1), Mn-SOD (SOD2), and EC-SOD (SOD3) gene structures, evolution and expression. Free Radic. Biol. Med., 33 (3), 337-49. 
INFLUENCE OF MODIFIED ATMOSPHERE PACKAGING AND COLD ... 329

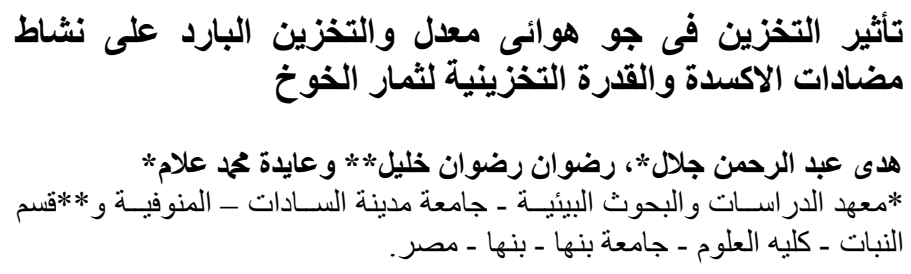

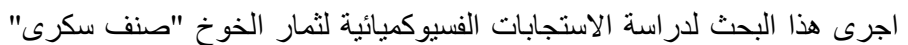

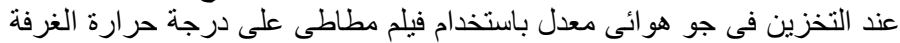

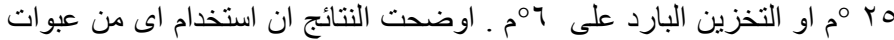

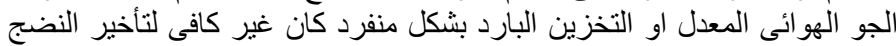

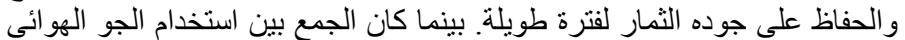

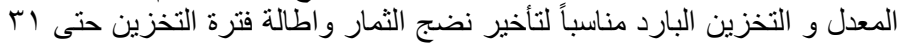

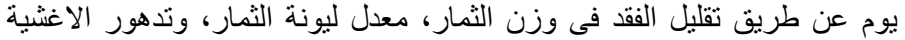

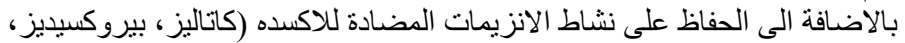

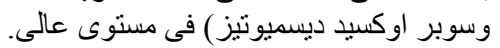

